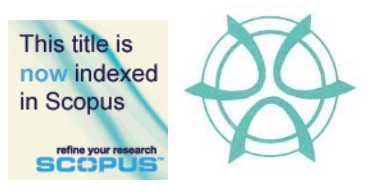

PLANNING MALAYSIA:

Journal of the Malaysian Institute of Planners

VOLUME 16 ISSUE 1 (2018), Page 1 - 14

\title{
ARCHITECTURAL PRACTICES OF PROJECT COMMUNICATION MANAGEMENT IN IRAQ
}

\author{
Hala Taleb Al-Mayahi ${ }^{1}$, Syuhaida Ismail ${ }^{2}$, Mohammad Hussaini Wahab ${ }^{3}$, \\ Wan Nurul Mardiah Wan Mohd Rani ${ }^{4}, \&$ Rohayah Che Amat ${ }^{5}$ \\ 1,2,3,4,5 Razak School of Engineering and Advanced Technology \\ UNIVERSITI TEKNOLOGI MALAYSIA, KUALA LUMPUR
}

\begin{abstract}
Architects are significant initiators for the built environment projects, while architecture is all about communicating effectively with clients. Yet, some problems occur in regard to the mutual transfer of project information between those two parties. Thus, it is essential to enrol a proper system for managing project communication through communication management. Communication management is a notable part of the project management body of knowledge that coordinates and manages the process of exchanging information of the designing projects. However, studies confirmed that practices of communication management are often underestimated and overlooked. This article discusses communication management from architects' perspectives with the objectives of determining the current practice in Iraq and examining the required communication competencies to improve it. An online questionnaire survey was administered via surveymonkey.com to 100 architects working in private firms in Basra City, south of Iraq. The collected data were analysed with Statistical Package of Social Sciences (SPSS) version 23. The analyses for the two objectives showed that Iraqi architects have little information and knowledge in project communication management, where standards and methodologies are not followed. The results also indicated the top-rated competencies to be obtained. Thus, this article concludes that there is a need to introduce communication management as an evolving knowledge area to the architects in Iraq, and develop its implementation through communication competencies that attempt to fulfil clients' requirement and aspirations regarding the architectural design.
\end{abstract}

Keyword: communication management, architects, practice, clients, Iraq, competency. 
Hala Taleb, Syuhaida, Mohammad Hussaini, Wan Nurul Mardiah, \& Rohayah

Architectural Practices of Project Communication Management in Iraq

\section{INTRODUCTION}

Architects are the first initiators of the direct communication process with the clients during the designing phase. Moreover, communication has an influential impact on the architectural practice among individuals and project teams (Shen, 2011). Communication is also the backbone of project success, and miscommunication may cause unpleasant consequences and delays that lead to project failure (Charvat, 2003). Therefore, an adequate communication management system is necessary to help avoid such problems (Foley \& Macmillan, 2005).

Communication management is a fundamental part of the project management field, as it controls the systematic information exchanges among the involved parties of the project (Muszynska, 2017). However, scholars claim that little attention was paid to the significance of communication management, and project management studies are also scarce (Dainty, Moore, \& Murray, 2006; Papke-Shields, Beise, \& Quan, 2010; Zulch, 2014). Therefore, Samáková, Sujanová and Koltnerová (2013) highlight the necessity of major changes and improvement in communication plans, as well as in managing the required communication. Subsequently, it is a demanding call to assist architects to set exquisite guidelines on communication management methods that ensure effective communication and correspondence with the features and environment of the project (Muszynska, 2017).

In Iraq, many studies have been conducted to investigate the implementations, practices and knowledge of project management in the Architecture, Engineering and Construction (AEC) industry. According to AlAgele and Ali (2017), Iraq's construction projects have significantly increased after the war in 2003 to reconstruct the caused damages. However, these projects were poorly planned and managed, resulting in less than intended results. Project management in AEC industry was confirmed to be evidently weak by Abdulmajeed (2017), who states that most of project managers in construction projects were architects. However, the study concluded that project managers were still practising to manage projects despite the little knowledge they hold in this field. Thus, scholars like Al-Samaraie and Al-Hasnawi (2016) suggest that there is a significant need to specifically focus in the communication between designers and clients, due to their roles in the overall construction project.

This research intends to outline the current implementations of communication management among Iraqi architects and to examine the required communication competencies to be adopted by architects to improve communication management. This research targets the architects working in the private sector in the city of Basra, Southern of Iraq, with a minimum of two years of experience. Data were obtained through self-administrated closed-ended online questionnaire survey. A pilot study was conducted for testing the reliability of the research instrument using Cronbach's alpha coefficient of internal 
PLANNING MALAYSIA

Journal of the Malaysia Institute of Planners (2018)

consistency. Refined questionnaires were then distributed to respondents through surveymonkey.com. The findings showed that little attention was given to project communication management in Iraq, where the practices among architects were considered weak. This article recommends that project communication management must be given sufficient attention by all parties in AEC industry as it is one of the vital parts in construction projects.

\section{LITERATURE REVIEW}

Human interaction is based on the mutual communication between two parties, or more. In architectural project, this relies on the communicating act between the architect and the client to reach a level of understanding that could ensure project success. Basically, the process of communication is composed of four elements, namely the sender, who encodes the information; the receiver, who decodes it; the message that is shared; and the channel, which is the medium of transferring data (Cheney et al., 2010). In the context of this research, the sender is the client, who shares his thoughts with the architect, who receives the message of the requested design and transfer it through the channel (Lunenburg, 2010).

Definitions of communication have been studied by scholars due to the significance that communication holds (Taleb, Ismail, Wahab, Rani, \& Amat, 2017). For Keyton (2010) and Barrett (2006), communication is a process of transferring information and produces mutual understanding between participants. Conversely, Den Otter and Prins (2002) see communication as the human behaviour, which facilitates the information and meaning sharing, while it is being adopted in a certain social context. In terms of architecture, communication is the backbone of this industry (Gabriel \& Maher, 2002), and it denotes two parties involved together, attempting to employ their common understanding of particular terms and conceptions related to the industry, through verbal and non-verbal channels. Establishing effective communication during the designing phase of a project is important to avoid project failure due to insufficient communication (Taleb et al., 2017). Since the architect is responsible for creating a convenient venue for discussion with the client (Norouzi, Shabak, Embi, \& Khan, 2015), and due to the big amount of information exchanges during the designing phase between client and architect, a coordinated management of exchanging data between the participants is required (Melzner, Feine, Hollermann, Rütz, \& Bargstädt, 2015).

Communication management is a notable area in the project management field that holds a critical effect on projects or organisations. To Riel (1995), it is an instrument of managing all the means and forms of internal and external communication, which are being commonly compatible to attain prosperous results. PMI (2013) identified communication management as one of the ten areas of project management, as it covers the processes needed to assure proper and intime actions to create, plan, disseminate, restore and manage the project-related 
Hala Taleb, Syuhaida, Mohammad Hussaini, Wan Nurul Mardiah, \& Rohayah

Architectural Practices of Project Communication Management in Iraq

information. Communication management is the basis of decision-making process throughout the total project time (Mnkandla, 2013), and it ensures adequate information is acquired at the right time and is sent to the right audience. The main features of communication management include developing strategies for corporate communications, setting instructions of communication processes and managing the flow of project information.

In Iraq, project communication management is hardly studied by those in the project management discipline. Nevertheless, Al Saffar, Raheem and Ghaleb (2014) emphasise the issues arise, such as time and effort loss, due to the patent weakness of communication management during the project planning. Moreover, they highlighted that the reason behind these issues was usually the little time given for planning project communication in comparison with other processes of the project. Therefore, they suggest management techniques and implementations to be developed to avoid communication breakdown and failure. Meanwhile, Ali and Nabil (2014) examine the effect of information and communication technology (ICT) on the local engineering projects and focused on the project's designing and planning phases from an architectural perspectives. They introduced the theoretical framework of ICT, value and implementations.

Architecture industry is project-based by its nature, and the understanding of project is a prerequisite, fulfilled by adopting proper management based on international standards, which are seen as a critical method of improving project management effectiveness (Young \& Wagner, 2015). This study discusses the PMBOK by the Project Management Institute (PMI) as one of the most related standards to the project communication management (Samáková et al., 2013). PMBOK is a set of guidelines in the project management field of knowledge, as it distinguishes the processes of project communication management into three: plan communication management, manage communication and control communication (PMI, 2013).

Plan communication management is a process in which approach and arrangement for effective communication schemes that are consistent with the stakeholder's needs and requirements are formulated. This process is undertaken at the initial stage of the project to assure efficient use of resources, time and budget. Furthermore, managing communication is about creating, collecting, disseminating, storing and retrieving project information. It ensures the communicated project information are well generated, received and understood (Taleb et al., 2017). Finally, plan communication is observing and controlling the communication throughout the project life to attain stakeholder's needs. It requires negotiations between the project parties to set the most relevant methods to increase project performance that satisfies stakeholder's requirements.

Required competencies must be possessed by architects to improve their communication management practices with their clients. A competency is an integration of many aspects to attain success in a particular job, such as 
PLANNING MALAYSIA

Journal of the Malaysia Institute of Planners (2018)

knowledge, individual behaviour and professionalism (Varajão \& Cruz-Cunha, 2013). In terms of project management, IPMA (2006) defines the competency as the potential that uses the owned skills and knowledge to show the person's distinctive features. Parry (1996) sees competency as a set of related knowledge, skills, behaviours and personal features that influence the individual's job, correspond to the performance of the work and can be improved with practice.

Due to the significant value of holding relevant competencies in project management, PMI (2007) presented the Project Manager's Competencies Development Framework (PMCDF), in which communicating falls under the personal competencies of the framework. This covers the exchange of accurate and pertinent information through relevant methods. It also demonstrates the person's ability in managing the project through performed attitudes, behaviours and personal characteristics. The personal competencies suggested by the framework were used as the fundamentals in developing the questionnaire used in this research.

\section{METHODOLOGY}

A close-ended self-administered online survey was employed as the method to obtain data. Online survey was selected since it is an instrument with increasing significance to survey population, less costly, faster to expand, with growing levels of response, less responding errors and notable flexibility (McDonald \& Adam, 2003). Baruch and Holtom (2008) also agree on the significance of online survey and stated that the response rate achieved by the online surveys could be equal or higher than those by emailing surveys. The questionnaire consisted of three sections: respondents' background, current practices and communication management competencies. Answers were categorised based on a 4 Likert scale measurement option, with 1 being strongly disagree and 4 strongly agree. Although studies are commonly using five responding options of Likert scale with the neutral option, this research follows Nemoto and Beglar (2014) who demonstrate that having a Likert scale of four or six measurement option can be more reliable. Similarly, Garland (1991) states that removing the neutral option helps to increase the reliability of responses.

The online survey was conducted among through surveymonkey.com. Respondents, who were practising architects in Basra City, Iraq, were sampled through the non-probability sampling method, where respondents were basically chosen with no probabilities of selection. This method was common among researchers who conducted studies among a particular group of respondents (Lemeshow, Hosmer, Klar, \& Lwanga, 1990), and results can be further generalized to the overall population. Some researchers consider setting criteria for the sample is a necessity to increase adequacy of the study (Muhwezi, Acai, \& Otim, 2014). Additionally, Kakepoto et al. (2012) suggest that setting a limitation in terms of working experience is essential, due to the gained 
Hala Taleb, Syuhaida, Mohammad Hussaini, Wan Nurul Mardiah, \& Rohayah

Architectural Practices of Project Communication Management in Iraq

understanding and perception of communication and feedback during this period. Thus, for the purpose of this research, sampled respondents must possess at least two years of experience of practising architecture, designing and dealing with clients within their practice. This research was undertaken in Basra City, where most of Basra architects got their degrees from University of Basra, where its Department of Architectural Engineering was only established in the academic year of 2001/2002. Therefore, the maximum working experience of Basra graduate architects is 10 years. Hence, sampling limitation of at least two years of working experience was adequate relative to maximum working experience of graduate architects in Basra.

Statistics show that the total population $(\mathrm{N})$ of practising architects in Basra who have at least two years of working experience was 150 . Therefore, following Krejcie and Morgan (1970) recommendation, a sample of 108 architects was selected.

A pilot study was then conducted to test the reliability of the survey instrument. The Cronbach's alpha coefficient of the pilot study was 0.845 , indicating acceptable consistency (George \& Mallery, 2011). Subsequently, the online survey was conducted in the period between $22^{\text {nd }}$ January and $14^{\text {th }}$ March 2017 , resulting in $82 \%$ response rate. Data collected through the survey were then analysed using Statistical Package for the Social Sciences (SPSS) software version 23. Descriptive data analysis was to calculate the mean, the standard deviation (SD), as well as the Relative Importance Index (RII). The mean is the most commonly used measure of the central tendency, as it refers to the scores' average which summarises the interval scores (Patel, 2009). For this research, scales of mean that range between 1.00 to 2.99 are considered low, whilst values $\geq 3.00$ are high and accepted. On the other hand, the standard deviation is the value of average distance for each element from the mean value.

Relative Importance Index (RII) is an analysis of relative importance, where it assesses the ranking of survey's questions in relation to other questions per survey's responses (Ismail, 2015). RII is calculated through the formula presented by Somiah, Osei-Poku, and Aidoo (2015):

Where:

$$
\mathrm{RII}=\frac{4(\mathrm{n} 4)+3(\mathrm{n} 3)+2(\mathrm{n} 2)+\mathrm{n} 1}{4(\mathrm{n} 1+\mathrm{n} 2+\mathrm{n} 3+\mathrm{n} 4)}
$$

$\mathrm{n} 1=$ the number of respondents who selected 1 (strongly disagree/ not at all important).

$\mathrm{n} 2=$ the number of respondents who selected 2 (disagree/ not important).

$\mathrm{n} 3=$ the number of respondents who selected 3 (agree/ important).

$\mathrm{n} 4=$ the number of respondents who selected 4 (strongly agree/ extremely important). 
In this context, the RII value ranges between 1 and 0 , and when the value increases, the importance of the factor increases subsequently. Thus, the studied elements are sorted ascending in tables, from the more important to the less important (Doloi, Sawhney, Iyer, \& Rentala, 2012).

\section{FINDINGS AND DISCUSSION}

The respondents' background is shown in Figure 1. This includes age, gender, affiliation (according to the Iraqi Engineers Union) and years of experience. In terms of gender, male and female respondents were almost equal in percentage, which were $50.6 \%$ and $49.4 \%$, respectively. The majority of the respondents were aged between 25 to 34 years old, with 25 years old was the minimum age to gain at least two years of experience in order to fulfil sampling requirement. As shown in Figure 1, 65.2\% of respondent were 25-29 year olds, whilst $29.2 \%$ were $30-34$ year olds. $1.1 \%$ age between 35 and 39 years old, where they represented the least percentage of respondents, and finally, $4.5 \%$ age more than 40 years old, and they usually represent the consulting architects and University lecturers. This demonstrates that the architects in Basra mostly belong to the Y generation. As previously mentioned, Y generation is one of the biggest cohorts among the workforces (Nightingale, 2011).

The respondents' age ranges affect their years of experience, where results show that it ranged between 2 and 10 years, due to the generation cohort they belong to, and to the relatively new established architectural engineering department in Basra University. 36\% have 2-4 years of experience, $37.1 \%$ have 2-7 years, and $21.3 \%$ have $8-10$ years of experience.

Finally, architects in Iraq follow the engineers' affiliation under the Iraqi Engineers Union. It consists of four categories, namely assistant engineer, practitioner engineer, licensed engineer and consultant engineer. Promotion between categories is time-based, where it takes at least 14 years before an assistant engineer could be promoted through the ranks to become consultant engineer. This is reflected in Figure 1 where, because of the youthful age of the respondents, the majority were assistant or practitioner engineers, which represent $39.3 \%$ and $41.6 \%$ respectively. In addition, the licensed engineer represented $13.5 \%$ of respondents, and the consultant engineers were only $5.6 \%$ of the total sample. 
Hala Taleb, Syuhaida, Mohammad Hussaini, Wan Nurul Mardiah, \& Rohayah Architectural Practices of Project Communication Management in Iraq

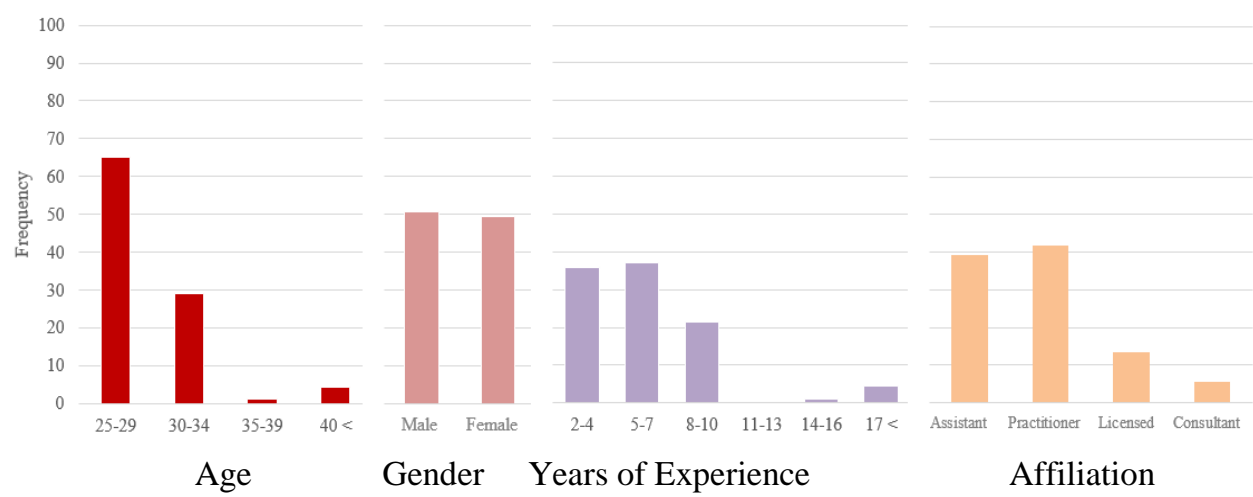

Figure 1: General demographic information

The questionnaire also consisted 13 questions regarding the current practice of project communication management in Iraq including the implementation of project communication planning, knowledge and compliance to international project management standards and methodologies, and the various applications of the communication management during the project design phase. Likert scale of 1 to 4 was used to record answers. Collected data were then analysed to determine the mean and standards deviation (SD), which are shown in Figure 2.

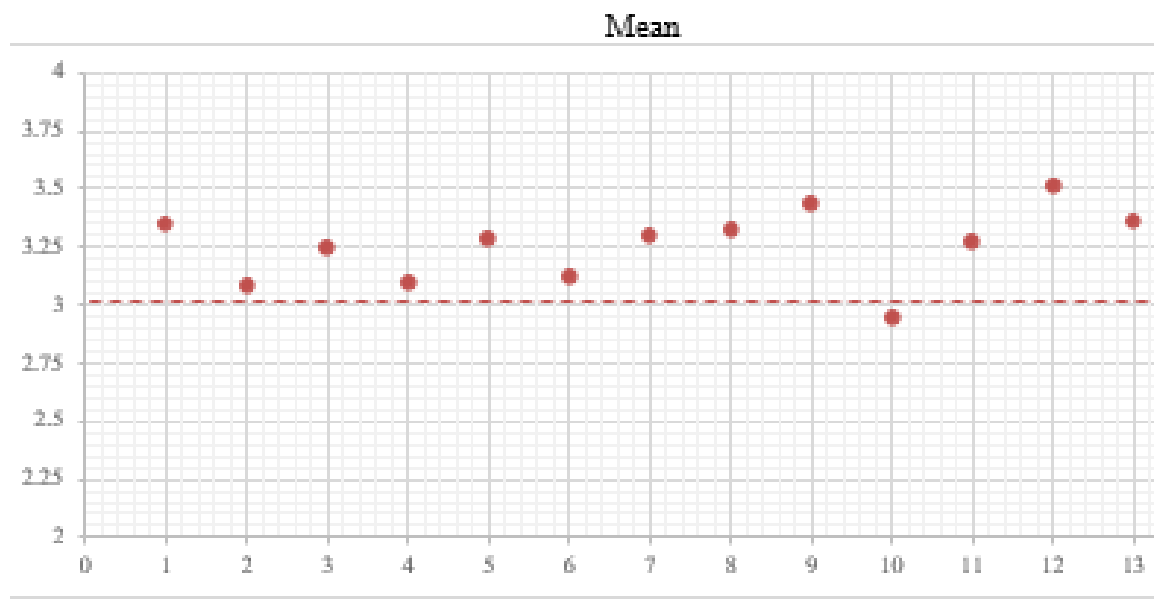


$\mathrm{SD}$

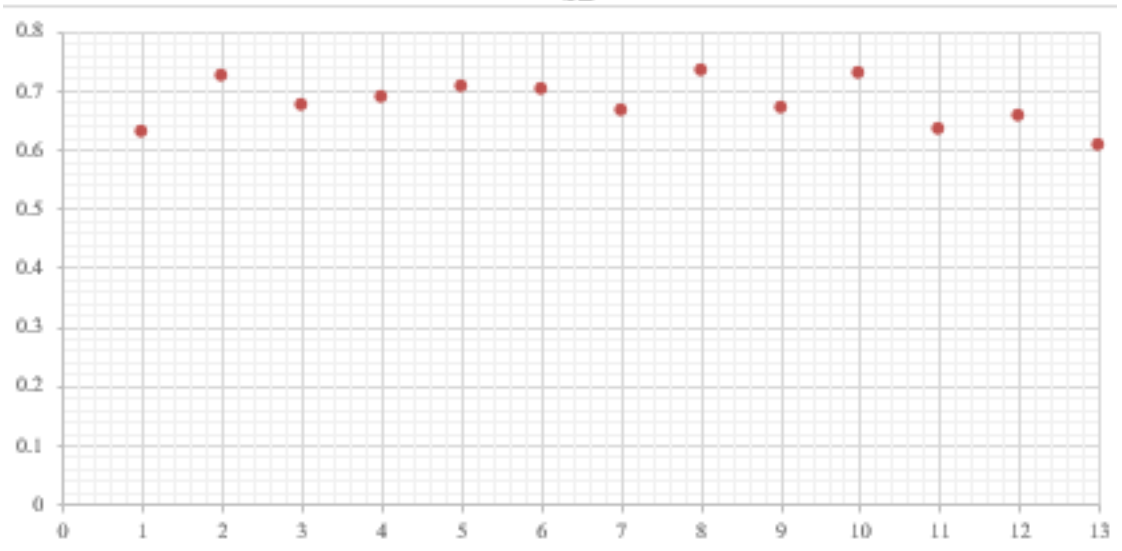

Figure 2: Distribution of mean and standard deviation values

Results show that architects had a unanimous agreement on the weak practices of project communication management, and little attention was given to the implementations of communication management. In addition, the international standards and methodologies, such as PMBOK and ICD, were not recognised or followed by the architects. However, architects saw a need to adopt proper communication methods with their clients, as well as to improve their communication skills to manage their relationships with clients. Thus, it is the architect's responsibility to propose, maintain, manage, perform and instruct the communication, in relevance to the project environment and requirements. These results are supported by the studies conducted by Samáková et al. (2013), Carvalho (2008) and Bilczynska Wojcik (2014), who also find that communication management was not given adequate attention, international standards of communication management were not followed, weak implementation of communication management plans, and significantly limited knowledge and practices of this field.

The final section of the questionnaire attempts to explore the competencies that should be obtained by architects to help them improve the process of communication with their clients. The leading five competencies of PMBOK that architects confirmed to be considerably adopted by them are listed in Table 1.

Table 1: Relative Importance Index (RII) values for PMBOK competencies

\begin{tabular}{llll}
\hline No. & $\begin{array}{l}\text { RII } \\
\text { Value }\end{array}$ & $\begin{array}{l}\text { Competency } \\
\text { (PMBOK) }\end{array}$ & Justification \\
\hline 1 & 0.907 & $\begin{array}{l}\text { Architects help } \\
\text { clients to } \\
\text { understand what }\end{array}$ & $\begin{array}{l}\text { In some occasions, clients are inexperienced and } \\
\text { have little information about the design, the } \\
\text { expectations and the requirements. The architect }\end{array}$
\end{tabular}


Hala Taleb, Syuhaida, Mohammad Hussaini, Wan Nurul Mardiah, \& Rohayah Architectural Practices of Project Communication Management in Iraq

\begin{tabular}{|c|c|c|c|}
\hline & & $\begin{array}{l}\text { they want and } \\
\text { can be achieved. }\end{array}$ & $\begin{array}{l}\text { needs to be able to demonstrate and share project } \\
\text { information properly and help the client to reach a } \\
\text { convenient understanding of the design potentials } \\
\text { (Shen, Shen, \& Sun, 2012). }\end{array}$ \\
\hline 2 & 0.907 & $\begin{array}{l}\text { Experience } \\
\text { makes } \\
\text { communication } \\
\text { with clients more } \\
\text { achievable and } \\
\text { manageable. }\end{array}$ & $\begin{array}{l}\text { To gain more experience through increasing the } \\
\text { years of working and dealing with clients can } \\
\text { enhance the architects' ability to understand the } \\
\text { clients' needs and to properly manage to } \\
\text { communicate, explain and exchange information } \\
\text { with them (Kakepoto et al., 2012). }\end{array}$ \\
\hline 3 & 0.904 & $\begin{array}{l}\text { Architects need } \\
\text { to build trust } \\
\text { with their clients. }\end{array}$ & $\begin{array}{l}\text { Trust is the ground base for any relationship and is } \\
\text { a critical success factor. An architect-client } \\
\text { relationship needs to be developed to a certain } \\
\text { level of trust, and it is the architect's responsibility } \\
\text { to take this action (Siva \& London, 2011). }\end{array}$ \\
\hline 4 & 0.902 & $\begin{array}{l}\text { It is essential to } \\
\text { guide the clients } \\
\text { to the correct } \\
\text { solutions and } \\
\text { techniques and } \\
\text { guide them to } \\
\text { communicate } \\
\text { effectively. }\end{array}$ & $\begin{array}{l}\text { As communication methods and techniques vary } \\
\text { according to the project, cooperation and effective } \\
\text { communication with clients have a direct impact } \\
\text { on the project success, where insufficient } \\
\text { collaboration is an impactful cause of low-end } \\
\text { innovation (Holmen, Pedersen, \& Torvatn, 2005). }\end{array}$ \\
\hline 5 & 0.865 & $\begin{array}{l}\text { Adopting proper } \\
\text { technological } \\
\text { talents of the } 3 \mathrm{D} \\
\text { visualisation as a } \\
\text { part of } \\
\text { communication } \\
\text { management. }\end{array}$ & $\begin{array}{l}\text { Architecture is the core of the world of } \\
\text { visualization, and 3D renderings or perspective } \\
\text { drawings are considered to be a critical approach } \\
\text { of communication between the client and the } \\
\text { architect (Kitchens \& Shiratuddin, 2007; Shen, } \\
\text { 2011). It helps the client to attain a clear } \\
\text { understanding of the design solutions. }\end{array}$ \\
\hline
\end{tabular}

Meanwhile, the leading five competencies as highlighted by the PMCDF are shown in Table 2 below.

Table 2: Relative Importance Index (RII) values for PMCDF competencies

\begin{tabular}{llll}
\hline No. & $\begin{array}{l}\text { RII } \\
\text { Value }\end{array}$ & $\begin{array}{l}\text { Competency } \\
\text { (PMCDF) }\end{array}$ & Justification \\
\hline 1 & 0.884 & $\begin{array}{l}\text { Provide accurate and } \\
\text { factual information. }\end{array}$ & $\begin{array}{l}\text { The significance of exchanging real } \\
\text { information between the client and the } \\
\text { architect to assure the desired final results are } \\
\text { fulfilled (Cheung, Yiu, \& Lam, 2013). }\end{array}$ \\
\hline 2 & 0.862 & $\begin{array}{l}\text { Use appropriate } \\
\text { information sources } \\
\text { (primary, secondary, } \\
\text { etc.). }\end{array}$ & $\begin{array}{l}\text { Sources of information are divided to primary } \\
\text { sources and secondary sources. The architect } \\
\text { needs to set the most relevant ones to the } \\
\text { designing project (Sindhu, 2011). }\end{array}$
\end{tabular}


0.862 Provide relevant information.

4

0.853 Align communication with environment or setting.

$5 \quad 0.842$ Actively listen.
Adopting the adequate presentation skills and getting feedback of the relevance level of information from the recipient (Hoezen, Reymen, \& Dewulf, 2006).

The selected methods of communication must be corresponded to the environment of the project and the needs and background of the client (Norouzi et al., 2015).

Architects need to carefully listen and respond to the received feedback and argument from the client regarding the project initiating and results (APM, 2012). In addition to being open to the other party's views and ideas.

\section{CONCLUSION}

By the end of this research, the current practice of project communication management, as a significant part of project management, has been determined through the responses collected from the architects in the City of Basra, Iraq. Results showed that architects have little knowledge in terms of project communication management, and international standards such as PMBOK and ICB were not practised. However, they agreed to the need to improve the implementation project communication management due to its significance in obtaining project success. Moreover, the communication skills and competencies that architects need to adopt were discussed according to those highlighted by PMBOK and PMCDF. Five competencies of each framework were found to be more effective. For PMBOK, these included help clients to understand the expectations, focus on enriching their experiences, build trust, guide client through project life, and develop $3 d$ visualisation technologies. While for PMCDF, they were provide accurate information, use appropriate sources, provide relevant information, align communication with environment, and use suitable communication methods.

It is hoped that the findings of this research would help the architects in Iraq to increase their knowledge and understanding regarding project communication management, so that it will increase the client-architect mutual understanding level, and ultimately project success.

\section{ACKNOWLEDGEMENT}

The authors would like to express their sincere gratitude to the Ministry of Education Malaysia, Universiti Teknologi Malaysia (UTM) and the Research Management Centre (RMC) of UTM for providing the financial support for this research to be published. This research is financed by the Grant of UTM Razak School for research funding under Cost Centre No. R.K130000.7740.4J290. 
Hala Taleb, Syuhaida, Mohammad Hussaini, Wan Nurul Mardiah, \& Rohayah

Architectural Practices of Project Communication Management in Iraq

\section{REFERENCES}

Abdulmajeed, N. S. (2017). Methods of controlling the engineering projects in Iraqi engineering consultant organizations. Journal of Babylon University, 25(6), 20552068.

Al-Agele, H. K., \& Ali, A. J. (2017). Mismanagement reasons of the projects execution phase. Journal of Engineering, 23(10), 15-29.

Al-Samaraie, S. H., \& Al-Hasnawi, A. A. H. (2016). The success of project management according to the characteristics of the changing organizational field research for the sample of workers in the general authority for roads and bridges. Journal of Economics and Administrative Sciences, 22(88), 130-157.

Al Saffar, A., Raheem, K., \& Ghaleb, A. A. (2014). Improving the performance of construction project information and communication management using webbased project management systems. Journal of Engineering, 20(10), 79-92.

Ali, S. A. H., \& Nabil, M. S. M. K. (2014). Effect of information and communication technology in the local engineering project management. Engineering \&amp; Technology Journal, 32(8 Part (A) Engineering), 257-274.

Association for Project Management [APM] (2012). APM body of knowledge. Association for Project Management.

Barrett, D. (2006). Leadership communication: McGraw-Hill: New York.

Baruch, Y., \& Holtom, B. C. (2008). Survey response rate levels and trends in organizational research. Human Relations, 61(8), 1139-1160.

Bilczynska Wojcik, A. (2014). Communication management within virtual teams in global projects. Dublin Business School.

Carvalho, M. M. (2008, July). Communication issues in projects management. Portland International Conference on Management of Engineering and Technology. July 27-31, 2008, Portland.

Charvat, J. (2003). Project management methodologies: selecting, implementing, and supporting methodologies and processes for projects. Hoboken, NJ: John Wiley \& Sons.

Cheney, G., Christensen, L. T., Zorn, T. E., \& Ganesh, S. (2010). Organizational communication in an age of globalization: Issues, reflections, practices (Second Edition). Prospect Heights: Waveland.

Cheung, S. O., Yiu, T. W., \& Lam, M. C. (2013). Interweaving trust and communication with project performance. Journal of Construction Engineering and Management, 139(8), 941-950.

Dainty, A., Moore, D., \& Murray, M. (2006). Communication in construction: Theory and practice. London: Taylor \& Francis.

Den Otter, A., \& Prins, M. (2002). Architectural design management within the digital design team. Engineering Construction and Architectural Management, 9(3), 162173.

Doloi, H., Sawhney, A., Iyer, K., \& Rentala, S. (2012). Analysing factors affecting delays in Indian construction projects. International Journal of Project Management, 30(4), 479-489.

Foley, J., \& Macmillan, S. (2005). Patterns of interaction in construction team meetings. CoDesign, 1(1), 19-37.

Gabriel, G. C., \& Maher, M. L. (2002). Coding and modelling communication in 
architectural collaborative design. Automation in Construction, 11(2), 199-211.

Garland, R. (1991). The mid-point on a rating scale: Is it desirable. Marketing Bulletin, 2(1), 66-70.

George, D., \& Mallery, P. (2011). SPSS for Windows step by step: A simple guide and reference 18.0 update. Boston, MA: Allyn \& Bacon/Pearson.

Hoezen, M., Reymen, I., \& Dewulf, G. (2006). The problem of communication in construction.

https://www.researchgate.net/publication/254858936_The_problem_of_commun ication_in_construction

Holmen, E., Pedersen, A.-C., \& Torvatn, T. (2005). Building relationships for technological innovation. Journal of Business Research, 58(9), 1240-1250.

IPMA (2006). ICB-IPMA competence baseline version 3.0. International Project Management Association: Nijkerk.

Ismail, M. F. (2015). Project management skills for new engineers in Jabatan Kerja Raya Malaysia (Master's Thesis), Universiti Teknologi Malaysia.

Kakepoto, I., Habil, H., Omar, N. A. M., Boon, Y., \& Hamdani, M. (2012). Oral communication skills of engineering students of Pakistan in perspective of industrial internships. International Journal of Applied Linguistics \& English Literature, 1(2), 170-176.

Keyton, J. (2010). Communication and organizational culture: A key to understanding work experiences. Thousand Oaks: Sage Publications.

Kitchens, K., \& Shiratuddin, M. F. (2007). Interactive Home design in a virtual environment. 7th International Conference on Construction Applications of Virtual Reality. October 22-23, 2007, Penn State University, USA.

Krejcie, R. V., \& Morgan, D. W. (1970). Determining sample size for research activities. Educational and Psychological Measurement, 30(3), 607-610.

Lemeshow, S., Hosmer, D. W., Klar, J., \& Lwanga, S. K. (1990). Adequacy of sample size in health studies. Chichester, UK: John Wiley and Sons Ltd.

Lunenburg, F. C. (2010). Communication: The process, barriers, and improving effectiveness. Schooling, 1(1), 1-11.

McDonald, H., \& Adam, S. (2003). A comparison of online and postal data collection methods in marketing research. Marketing Intelligence \& Planning, 21(2), 85-95.

Melzner, J., Feine, I., Hollermann, S., Rütz, J., \& Bargstädt, H. (2015, October). The influence of building information modelling on the communication management of construction projects. 15th International Conference on Construction Applications of Virtual Reality, October 5-7, Banff, Canada.

Mnkandla, E. (2013). A review of communication tools and techniques for successful ICT projects. The African Journal of Information Systems, 6(1), 1.

Muhwezi, L., Acai, J., \& Otim, G. (2014). An assessment of the factors causing delays on building construction projects in Uganda. International Journal of Construction Engineering and Management, 3(1), 13-23.

Muszynska, K. (2017). Patterns of communication management in project teams. In: Ziemba E. (Eds), Information technology for management: new ideas and real solutions. S.1.: Springer International PU.

Nemoto, T., \& Beglar, D. (2014). Developing Likert scale questionnaires. In JALT2013 Conference Proceedings. JALT: Tokyo. 
Hala Taleb, Syuhaida, Mohammad Hussaini, Wan Nurul Mardiah, \& Rohayah

Architectural Practices of Project Communication Management in Iraq

Nightingale, A. (2011). Millennial at work, reshaping the workplace. URL: http://www. pwc. ru/en_RU/ru/hr-consulting/publications/assets/millenials-survey. pdf (dama обрашения.

Norouzi, N., Shabak, M., Embi, M. R. B., \& Khan, T. H. (2015). The architect, the client and effective communication in architectural design practice. Procedia-Social and Behavioral Sciences, 172, 635-642.

Papke-Shields, K. E., Beise, C., \& Quan, J. (2010). Do project managers practice what they preach, and does it matter to project success? International Journal of Project Management, 28(7), 650-662.

Parry, S. B. (1996). Just What Is a Competency? (And Why Should You Care?). Training, $35(6), 58$.

Patel, P. (2009). Introduction to Quantitative Methods. Paper presented at the Empirical Law Seminar.

Project Management Institute [PMI] (2007). Project Manager Competency Development (PMCD) Framework. Project Management Institute.

Project Management Institute [PMI] (2013). A Guide to the Project Management Body of Knowledge: PMBOK Guide. Project Management Institute.

Riel, C. B. (1995). Principles of corporate communication. London: Prentice Hall.

Samáková, J., Sujanová, J., \& Koltnerová, K. (2013). Project communication management in industrial enterprises. 7th European Conference on Information Management and Evaluation, ECIME 2013. 155-163.

Shen, W. (2011). A BIM-based Pre-occupancy Evaluation Platform (PEP) for facilitating designer-client communication in the early design stage. The Hong Kong Polytechnic University.

Shen, W., Shen, Q., \& Sun, Q. (2012). Building Information Modeling-based user activity simulation and evaluation method for improving designer-user communications. Automation in Construction, 21, 148-160.

Sindhu, A. (2011). Sales promotion strategy of selected companies of FMCG Sector in Gujarat Region. (Doctorate Dissertation), Saurashtra University, Rajkot, India.

Siva, J. P. S., \& London, K. (2011). Investigating the role of client learning for successful architect-client relationships on private single dwelling projects. Architectural Engineering and Design Management, 7(3), 177-189.

Somiah, M., Osei-Poku, G., \& Aidoo, I. (2015). Relative importance analysis of factors influencing unauthorized siting of residential buildings in the Sekondi-Takoradi Metropolis of Ghana. Journal of Building Construction and Planning Research, 3(03), 117.

Taleb, H., Ismail, S., Wahab, M. H., Rani, W. N. M. W. M., \& Amat, R. C. (2017). An overview of project communication management in construction industry projects. Journal of Management, Economics, and Industrial Organization, 1(1), 1-8.

Varajão, J., \& Cruz-Cunha, M. M. (2013). Using AHP and the IPMA Competence Baseline in the project managers selection process. International Journal of Production Research, 51(11), 3342-3354.

Young, M., \& Wagner, R. (2015). PRINCE2® and the IPMA® Competence Baseline $(I C B 囚 3)$.

Zulch, B. (2014). Communication: The foundation of project management. Procedia Technology, 16, 1000-1009 